\title{
Harnessing Women's Potential as a Soft Engine for Growth - Lessons from Contrasting \\ Trajectories between Finland and Japan for Growing Economies
}

\author{
Chihiro Watanabe ${ }^{\mathrm{a}, \mathrm{b}}$ \\ Kashif Naveed $^{\text {a }}$ \\ Pekka Neittaanmäki ${ }^{\mathrm{a}}$ \\ ${ }^{a}$ Faculty of Information Technology, University of Jyväskylä, Finland. \\ ${ }^{b}$ International Institute for Applied Systems Analysis (IIASA), Austria.
}

\begin{abstract}
Harnessing the vigor of women's potential is essential for inclusive economic growth in a digital economy moving toward aging society. This can be a soft engine for sustainable growth substitutable for costly hard investment. While there exists explicit evidence of a virtual cycle between economic growth and gender balance improvement, emerging countries cannot afford to overcome the constraints of low income. Given the foregoing, this paper analyzed possible co-evolution between economic growth, gender balance improvement and digital innovation initiated by information and communication technology (ICT) advancement. Using a unique dataset representing the state of gender balance improvement in the function of economic growth and ICT advancement, an empirical numerical analysis of 44 countries was attempted. These countries were classified as emerging, industrialized and with a specific culture. It was found that while industrialized countries, typically Finland, have realized high performance in co-evolution, emerging countries have been constrained by low ICT advancement, and countries with a specific culture have, notwithstanding their high economic level, also been constrained by a traditional male-dominated culture. Japan is a typical case. Based on these findings, lessons from contrasting trajectories between Finland and Japan for emerging countries were analyzed. It is suggested that advancement of ICT, not only quantitatively but also qualitatively in such a way as constructing a self-propagating system, is crucial for emerging countries. A new practical approach for harnessing the potential resources for sustainable growth was thus explored.
\end{abstract}

Keywords: Gender balance, Gender balance intensity, Women board members, Trilateral co-evolution, Cultural dimension, Self-propagation

\section{INTRODUCTION}

Bridging the gender divide is not only a matter of fairness but also of effective governance and inclusive economic growth (OECD, 2016). It was demonstrated that companies with more women board directors experienced higher financial performance (Catalyst, 2005). Companies where women are most strongly represented at board or top-management level are also the companies that

Journal of Technology Management for Growing Economies Vol. 8, No. 1 April 2017 pp. 67-92

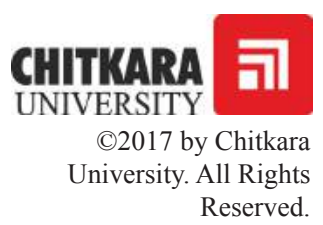


Watanabe, $\mathrm{C}$.

Naveed, K.

Neittaanmäki, P. perform best (McKinsey \& Company, 2007). Women's presence in the labour market is increasingly significant for economic growth and development at both nation and enterprise levels. The growing participation of women in the labor market has been a major engine of global growth and competitiveness (ILO, 2015). Harnessing the vigor of women potential is essential for inclusive economic growth in a digital economy moving toward aging society. This can be considered as a soft engine for sustainable growth substitutable for costly hard investment which is particularly important for emerging economies (Jia et al., 2013). For industrialized economies, this would help overcome the low growth and low birth rates of this era (Kim, 2015). A growing body of evidence shows that utilizing the skills and talent of both men and women is beneficial for enterprises and society in general (ILO, 2015).

However, despite growing awareness of the benefits of gender equality in decision-making, the pace of progress to achieve it is slow and varies considerably across countries (UNWomen, 2015; OECD, 2016; FINNCHAM, 2016). WEF (2016) urged the urgency of a fresh call to action to accelerate progress towards gender equality for harnessing women talent, half of the world's talent, towards the Fourth Industrial Revolution.

To date, a number of studies have identified the sources impeding gender balance improvement. OECD (2014) pointed out a range of external and internal barriers present in all areas of the public domain including: cultural barriers, structural barriers, lack of gender-disaggregated evidence and accountability mechanisms, and self-imposed barriers. UNDP (2010) revealed that while there exists explicit evidences on a virtual cycle between economic growth and gender balance improvement, emerging countries cannot afford to overcome the constraints of low income. UNESCO (2014) pointed out the limit of scientific resources for women initiative. McKinsey \& Company (2016) stressed a clear link between gender equality in society and gender equality in the workplace and also the proportion of women on executive committees and corporate performance.

In correspond to the increasing efforts of these identification and subsequent efforts in providing effective solution to eliminating impediments, a wealth of resources, good practices, organizational structures and networks are already in place (ILO, 2015). New initiatives have flourished in many areas (EC, 2017).

However, given the institutional complexity of the issue with considerable variety across countries, uniformed non-systematic approaches are hardly satisfactory for gaining timely solution.

In light of the foregoing, this paper, aiming at providing practical solution depending on the institutional states of the nations in a digital economy,

Journal of Technology Management for Growing Economies, Volume 8, Number 1, April 2017 
analyzed a possible trilateral co-evolution between economic growth, gender balance improvement and digital innovation initiated by information and communication technology (ICT) advancement taking cultural dimensions of the nations that impede gender balance improvement into account.

Using a unique dataset representing the state of gender balance improvement in the function of economic growth, ICT advancement and cultural dimensions, an empirical numerical analysis of 44 countries was undertaken. Through gender balance inspection by means of gender balance intensity it was identified that these countries could be classified into countries of emerging, industrialized and with specific culture.

It was found that while industrialized countries, typically Finland, have accomplished high performance in this trilateral co-evolution, emerging countries have been constrained by the low ICT advancement, and countries with specific culture have, notwithstanding their high level of economy and ICT dependency, also constrained by traditional male-dominated culture. Japan is a typical case.

Based on these findings, lessons from success and failure in gender balance improvement in advanced countries for emerging countries were developed by analyzing contrasting gender balance improvement trajectories between Finland and Japan, typical examples of success and failure.

It is suggested that advancement of ICT in such a way as enabling gender balanced organization leadership increase in a self-propagating way is crucial for emerging countries.

A new practical approach for harnessing the potential resources for sustainable growth was thus explored.

This paper is organized as follows: Section 2 analyzes pathways to gender balanced organization leadership. Section 3 demonstrates gender balanced leadership in digital economy. Lessons from contrasting trajectories between Finland and Japan is presented in Section 4. Section 5 briefly summarizes noteworthy findings, implications, and suggestions for future works.

\section{PATHWAYS TO GENDER BALANCED ORGANIZATION LEADER- SHIP}

\section{State of Parity between Gender}

Table 1 compares global rank of parity state between gender over the period 2012-2016. Table 1 demonstrates that while Iceland, Finland, Norway and Sweden share top four position, Japan demonstrates extremely behind position, not only the last position among G8 countries but also lower than 100 rank in all periods examined.

Journal of Technology Management for Growing Economies, Volume 8, Number 1, April 2017
Harnessing

Women's

Potential as a

Soft Engine 
Watanabe, $\mathrm{C}$.

Table 1: Global Rank of Parity State between Gender (2012-2016)

Naveed, K.

Neittaanmäki, P.

\begin{tabular}{|c|c|c|c|c|c|c|c|c|c|}
\hline & 1 & 2 & 3 & 4 & \multicolumn{4}{|c|}{ G8 countries } & $\begin{array}{c}\text { Re- } \\
\text { marks }\end{array}$ \\
\hline \multirow[b]{2}{*}{2016} & \multirow[b]{2}{*}{ Iceland } & \multirow[b]{2}{*}{ Finland } & \multirow[b]{2}{*}{ Norway } & \multirow[b]{2}{*}{ Sweden } & DEU(13) & $\operatorname{FRA}(17)$ & $\operatorname{GBR}(20)$ & CAN(35) & \multirow{2}{*}{$\begin{array}{c}\text { Out of } \\
144 \\
\text { coun- } \\
\text { tries }\end{array}$} \\
\hline & & & & & $\mathrm{USA}(45)$ & $\operatorname{ITA}(50)$ & RUS(75) & $\mathrm{JPN}(111)$ & \\
\hline \multirow{2}{*}{2015} & \multirow{2}{*}{ Iceland } & \multirow{2}{*}{$\begin{array}{l}\text { Nor- } \\
\text { way }\end{array}$} & \multirow{2}{*}{ Finland } & \multirow{2}{*}{ Sweden } & $\operatorname{DEU}(11)$ & FRA(15) & GBR(18) & USA(28) & \multirow{2}{*}{$\begin{array}{c}\text { idem } \\
145\end{array}$} \\
\hline & & & & & CAN(30) & $\operatorname{ITA}(41)$ & RUS(75) & JPN(101) & \\
\hline \multirow{2}{*}{2014} & \multirow{2}{*}{ Iceland } & \multirow{2}{*}{ Finland } & \multirow{2}{*}{ Norway } & \multirow{2}{*}{ Sweden } & DEU(12) & $\operatorname{FRA}(16)$ & CAN(19) & USA(20) & \multirow{2}{*}{$\begin{array}{c}\text { idem } \\
142\end{array}$} \\
\hline & & & & & GBR(26) & ITA(69) & RUS(75) & JPN(104) & \\
\hline \multirow{2}{*}{2013} & \multirow{2}{*}{ Iceland } & \multirow{2}{*}{ Finland } & \multirow{2}{*}{ Norway } & \multirow{2}{*}{ Sweden } & DEU(14) & GBR(18) & $\mathrm{CAN}(20)$ & $\mathrm{USA}(23)$ & \multirow{2}{*}{$\begin{array}{c}\text { idem } \\
136\end{array}$} \\
\hline & & & & & $\operatorname{FRA}(45)$ & RUS(61) & $\operatorname{ITA}(71)$ & JPN(105) & \\
\hline \multirow{2}{*}{2012} & \multirow{2}{*}{ Iceland } & \multirow{2}{*}{ Finland } & \multirow{2}{*}{ Norway } & \multirow{2}{*}{ Sweden } & DEU(13) & GBR(18) & $\mathrm{CAN}(21)$ & USA(22) & \multirow{2}{*}{$\begin{array}{c}\text { idem } \\
135\end{array}$} \\
\hline & & & & & $\operatorname{FRA}(57)$ & RUS(59) & ITA(80) & $\mathrm{JPN}(101)$ & \\
\hline
\end{tabular}

* DEU: Germany, FRA: France, GBR: UK, CAN: Canada, ITA: Italy, RUS: Russia, JPN: Japan**Figures in parenthesis indicate rank.

Sources: The Global Gender Gap Report 2012-2016 (World Economic Forum, annual issues).

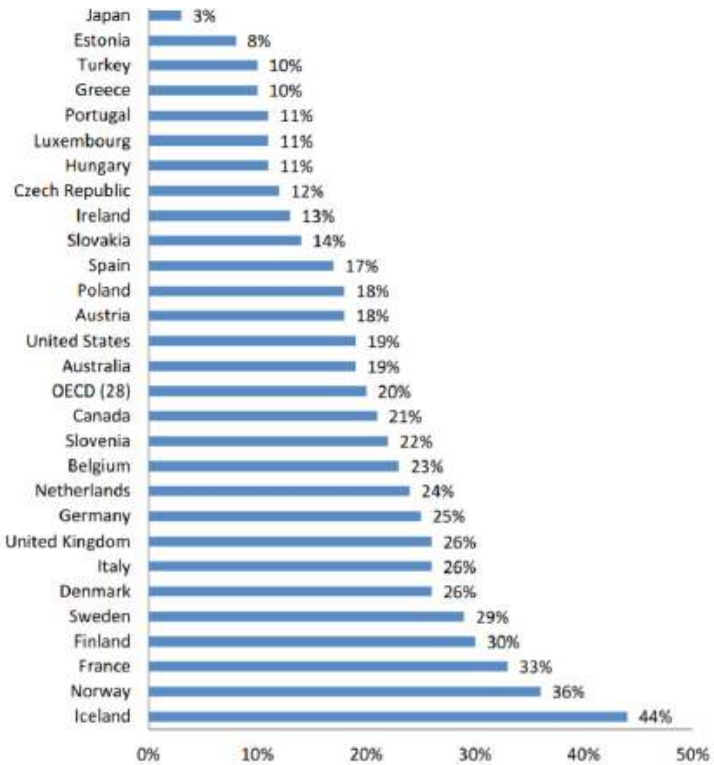

Figure 1: Share of Women Board Members at Companies in the OECD 29 Countries (2015).

Source: Background Report, Conference on Improving Women's Access to Leadership (OECD, 2016).

Original sources: Database on Women and Men in Decision Making (EC, 2016), Catalyst Census: Women Board Directors (Catalyst, 2015).

Journal of Technology Management for Growing Economies, Volume 8, Number 1, April 2017 
This contrast with respect to parity state between gender exactly corresponds to the share of women board members at companies which represents gender balanced corporate leadership (GMI Ratings, 2013; MSCI, 2015; OECD, 2016; FINNCHAM, 2016; McKinsey \& Company, 2016). Fig. 1 compares this share in the OECD 29 countries. Fig. 1 demonstrates that Iceland, Finland, Norway and Sweden which demonstrate world top position in parity state between gender share top 5 position also in the share of women board members at companies, while Japan demonstrates the last position also in this share. This correspondence suggests that the share of women board members at companies represents the state of gender balance. As reviewed earlier, McKinsey \& Company $(2007,2016)$ demonstrated clear link between women board member share - corporate performance - gender quality in the workplace - gender quality in society.

\section{Corporate Performance Improvement by Gender Balanced Leadership}

Companies with higher share of women board members experience higher financial performance.

Fig. 2 demonstrates outperformance of such companies as 53\%, $42 \%$ and $66 \%$ higher in return on equity (ROE), return on sales and invested capital, respectively in company with the highest share of women board members in Fortune 500 companies in comparison with that of the least share.

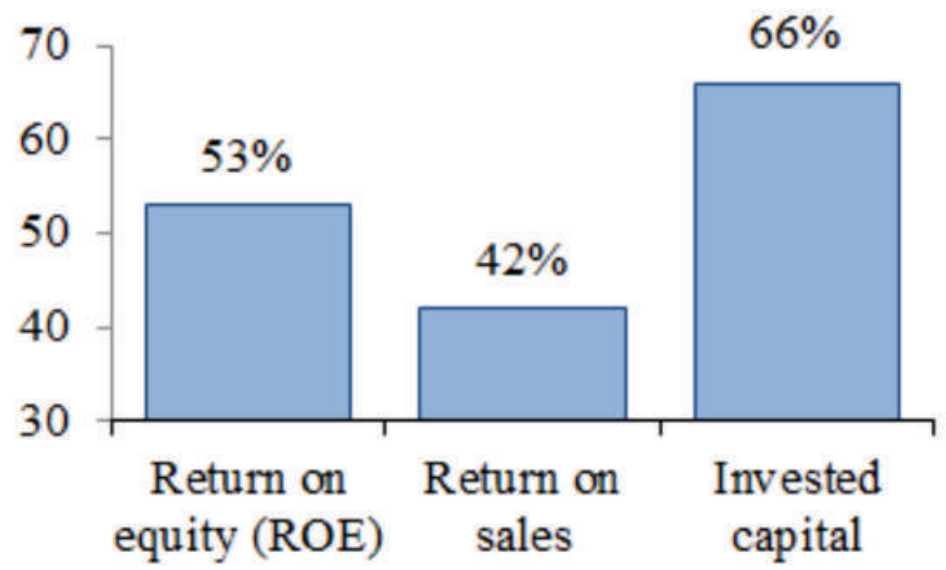

Figure 2: Outperformance Ratio of Women Board Directors Leadership in Fortune 500 Companies - Comparison between Highest and Least Share of WBDs (Average in 2001-2004).

Source: Catalyst, "Coroprate Performance and Women's Representation on Boards (2005). WBDs: Women Board Directors.

Journal of Technology Management for Growing Economies, Volume 8, Number 1, April 2017
Harnessing

Women's

Potential as a

Soft Engine 
Watanabe, C.

Naveed, K.

Neittaanmäki, P.

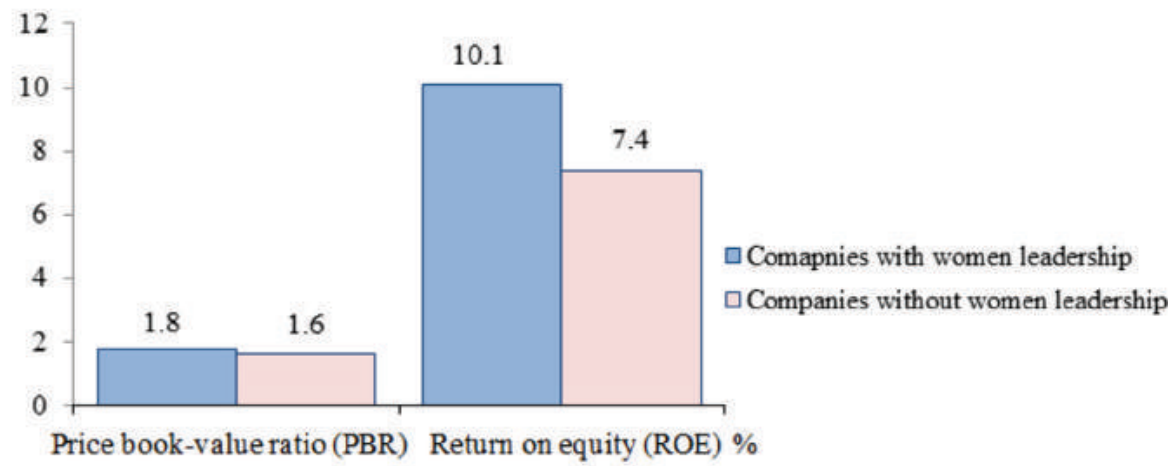

Figure 3: Financial Characteristics of Companies with Strong Women Leadership in MSCI World Companies (2015).

Source: MSCI ESG Research (2015).

Similar contrast can be observed also in Fig. 3 which conducted similar comparison by comparing premium returns and superior average valuation taking price book-value ratio (PBR) and ROE in MSCI world companies. Companies with strong women leadership demonstrated higher performance than companies without women leadership as $1.8 \%$ vs $1.6 \%$ and $10.1 \%$ vs $7.4 \%$., respectively.

Fig. 4 provides further supportive evidence by comparing PBR, ROE and operating profit growth between Japan's listed firms with 3\% of women board members (average of listed firms) and those with more than $10 \%$ of women board members.

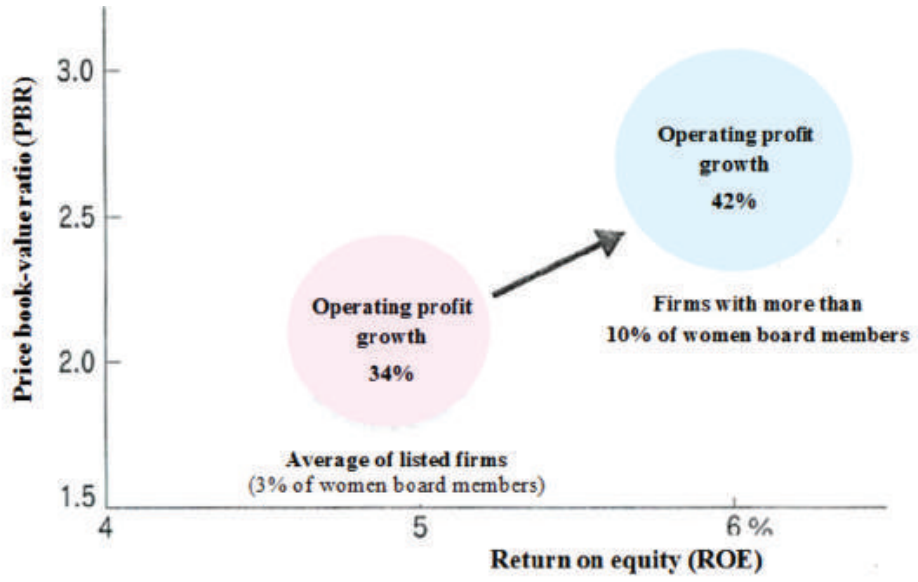

Figure 4: Correlation between Share of Women Board Members and Business Performance in Japan's Firms (2015).

Size of the circles demonstrates the magnitude of operating profit growth. Source: Nihon Keizai Shimbun (Feb. 4, 2017). 
All demonstrates significant corporate performance improvement by means of gender balance improvement represented by women board members share increase.

\section{Intensity of Gender Balanced Corporate Leadership}

\section{Gender Balance Index}

On the basis of the preceding reviews, aiming at assessing the effects of economic performance through gender balance improvement, gender balance index (GBI) that represents the state of gender balance affecting economic performance was constructed. Table 2 tabulates GBI in 44 countries in 2013 with comparison of similar values surveyed by OECD and WEF. GBI depended on GMI Rating's 2013 Women on Board Survey (GMI Ratings, 2013) which includes data in 2013 on 5977 companies in 45 countries around the world.

Table 2: Gender Balance Index (GBI) in 44 Countries (2013)

\begin{tabular}{|c|c|c|c|c|}
\hline Country & Code & $\begin{array}{c}\text { GBI } \\
(2013)\end{array}$ & OECD $(2015)^{*}$ & $\underset{(2016)^{* *}}{\mathbf{W E F}}$ \\
\hline Norway & NOR & 36.1 & 38 & 56 \\
\hline Sweden & SWE & 27.0 & 27 & 41 \\
\hline Finland & FIN & 26.8 & 28 & 43 \\
\hline France & FRA & 18,3 & 33 & 49 \\
\hline South Africa & ZAF & 17.9 & & \\
\hline Denmark & DNK & 17.2 & 24 & 35 \\
\hline Netherlands & NLD & 17.0 & 25 & 32 \\
\hline Israel & ISR & 15.7 & & \\
\hline New Zealand & NZL & 15.1 & & \\
\hline Germany & DEU & 14.1 & 24 & 33 \\
\hline Australia & AUS & 14.0 & 19 & 24 \\
\hline USA & USA & 14.0 & 19 & 24 \\
\hline Poland & POL & 13.6 & 15 & 22 \\
\hline Canada & CAN & 13.1 & 21 & 27 \\
\hline Turkey & TUR & 12.7 & 9 & 11 \\
\hline UK & GBR & 12.6 & 24 & 35 \\
\hline Austria & AUT & 11.3 & 17 & 22 \\
\hline Switzerland & CHE & 10.0 & 17 & \\
\hline Thailand & THA & 9.7 & & \\
\hline Hong Kong & HKG & 9.5 & & \\
\hline
\end{tabular}

Journal of Technology Management for Growing Economies, Volume 8, Number 1, April 2017
Harnessing

Women's

Potential as a

Soft Engine 
Watanabe, $\mathrm{C}$.

Naveed, K.

Neittaanmäki, P.

\begin{tabular}{|c|c|c|c|c|}
\hline Country & Code & $\begin{array}{c}\text { GBI } \\
(\mathbf{2 0 1 3})\end{array}$ & $\operatorname{OECD}(2015)^{*}$ & $\begin{array}{l}\text { WEF } \\
(2016)^{* *}\end{array}$ \\
\hline Spain & ESP & 9.5 & 17 & 21 \\
\hline Belgium & BEL & 9.2 & 23 & 30 \\
\hline Ireland & IRL & 8.7 & 11 & 15 \\
\hline Czech Republic & $\mathrm{CZE}$ & 8.6 & 7 & 14 \\
\hline China & $\mathrm{CHN}$ & 8.4 & & \\
\hline Italy & ITA & 8.2 & 24 & 35 \\
\hline Philippines & PHL & 7.9 & & \\
\hline Greece & GRC & 7.0 & 9 & 11 \\
\hline Singapore & SGP & 6.9 & & \\
\hline Malaysia & MYS & 6.6 & & \\
\hline India & IND & 6.5 & & 11 \\
\hline Peru & PER & 6.3 & & \\
\hline Columbia & $\mathrm{COL}$ & 6.0 & & \\
\hline Indonesia & IDN & 6.0 & & \\
\hline Mexico & MEX & 5.8 & & \\
\hline Brazil & BRA & 5.1 & & \\
\hline Russia & RUS & 4.8 & & \\
\hline Hungary & HUN & 4.5 & 12 & 12 \\
\hline Taiwan & TWN & 4.4 & & \\
\hline Egypt & EGY & 4.4 & & \\
\hline Portugal & PRT & 3.7 & 9 & 12 \\
\hline Chile & CHL & 2.8 & & \\
\hline Korea (Rep.) & KOR & 1.9 & & \\
\hline Japan & JPN & 1.1 & 3 & 3 \\
\hline
\end{tabular}

*Share of female board members at companies (\%), **Share of female in boards of publicly traded companies (\%).

Original sources GBI: GMI Ratings'2013 Women on Boards Survey (GMI Ratings, 2013). OECD: Background Report, Conference on Improving Women's Access to Leadership (OECD, 2016). WEF: The Global Gender Gap Report 2016 (WEF, 2016).

In order to examine the reliability of the GBI, comparative analysis with similar data surveyed by OECD and WEF was conducted. Fig. 5 compares 3 values with correlation analysis between OECD data and GBI as well as WEF and GBI. While there exists certain differences in some countries values (e.g., FRA, TUR, GBR and ITA), GBI can be considered to represent global gender 
balance position with reasonable correlation with those surveyed by OECD and WEF.

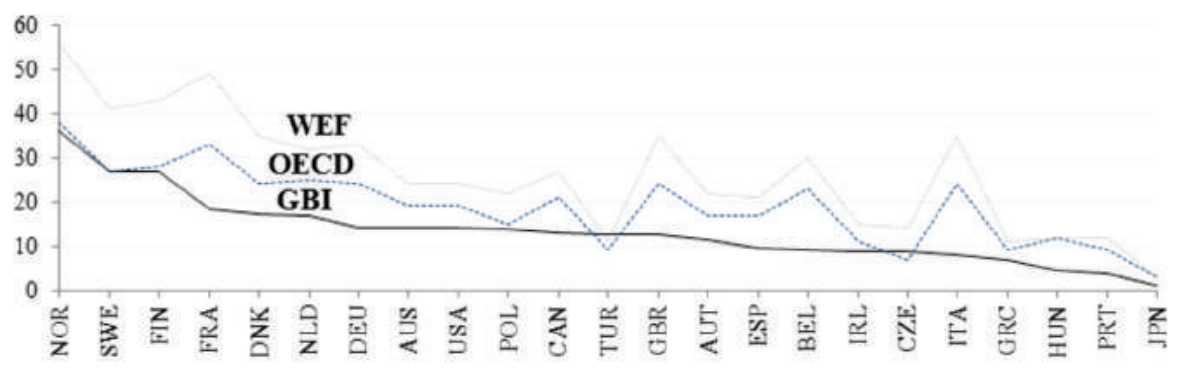

Figure 5: Comparison of Gender Balance Measurement in 23 Countries.

$\ln Y=-0.789+1.12 \ln O E C D+0.873 D$

$$
(-2.09 *)(8.56)
$$

Y: GBI; D: Dummy variable $(\mathrm{TUR}=1$, others $=0)$.

$\ln \mathrm{Y}=-0.920+1.053 \ln \mathrm{WEF}+0.936 \mathrm{D}$ adj. R2 0.834

$$
(-2.89) \quad(10.61)
$$

D: Dummy variable $($ TUR $=1$, others $=0)$.

\section{Gender Balance Intensity}

With the foregoing understanding, Fig. 6 demonstrates gender balance intensity by dividing GBI by GDP per capita in 44 countries (see Appendix 1 details of institutional states of 44 countries).

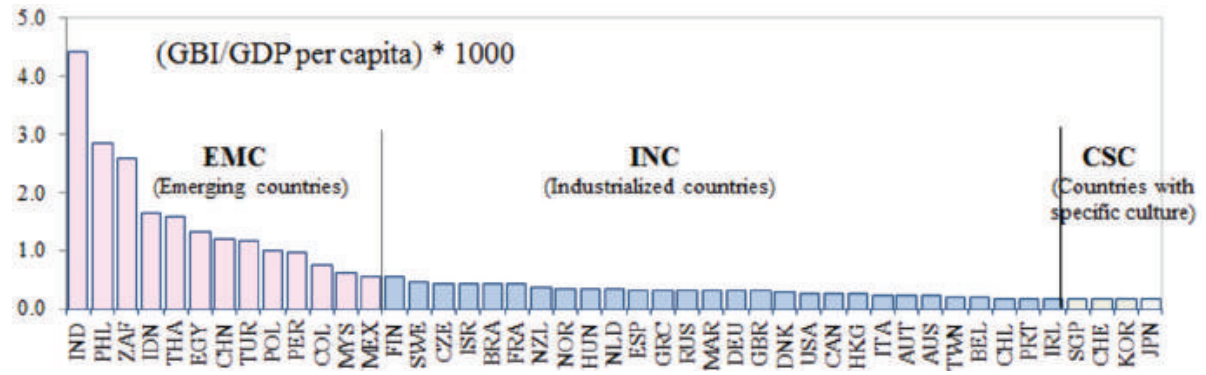

Figure 6: Gender Balance Intensity in 44 Countries (2013).

Looking at Fug. 6 we note that 44 countries can be classified into 3 groups: emerging countries (EMC), industrialized countries (INC) and countries with specific culture (CSC: see below). EMC include 13 countries with lower GDP per capita level than 10,000 US\$ (except POL: 13,700 US\$). INC includes

Journal of Technology Management for Growing Economies, Volume 8, Number 1, April 2017
Harnessing Women's

Potential as a Soft Engine 
Watanabe, $\mathrm{C}$. Naveed, K.

Neittaanmäki, P.
27 countries with higher GDP per capita level than 20,000 US\$ (except BRA $(12,260)$, HUN $(13,560)$, RUS $(15,560)$, CHL $(15,710))$. Finland demonstrates the top position in this group. CSC include 4 countries with the lowest level of GBI intensity: SGP, CHE, KOR and JPN. While they are highly industrialized, incorporating tradition of male-dominated society.

\section{Cultural Barriers against Gender Balance}

Fig. 6 suggests that GBI intensity is subject to cultural dimension of countries. Hofstede (1991) postulated that nations culture can be attributed to five dimensions as "Power distance" (inequality), "Individualism" (degree to which individuals are integrated into groups), "Masculinity" (distribution of roles between the genders), "Uncertainty avoidance" (extent a culture programs its members to feel either uncomfortable or comfortable in unstructured situations), and "Long-term orientation." Nations gender balance can largely be attributed to "Individualism" and Masculinity" together with their income level (see Appendix 2 details of these concepts). EMC belongs to low income level countries and CSC depends on high "intensified Masculinity density" (highly intensified male-dominated society) (see Appendix 3).

With such understanding, Fig. 7 demonstrates econo-cultural dimension of 44 countries by displaying their positions in two-dimensional landscape by GDP per capita and masculinity/ individualism ratio. Looking at Fig. 7 we note that it demonstrates similar clusters as classified in Fig. 6.

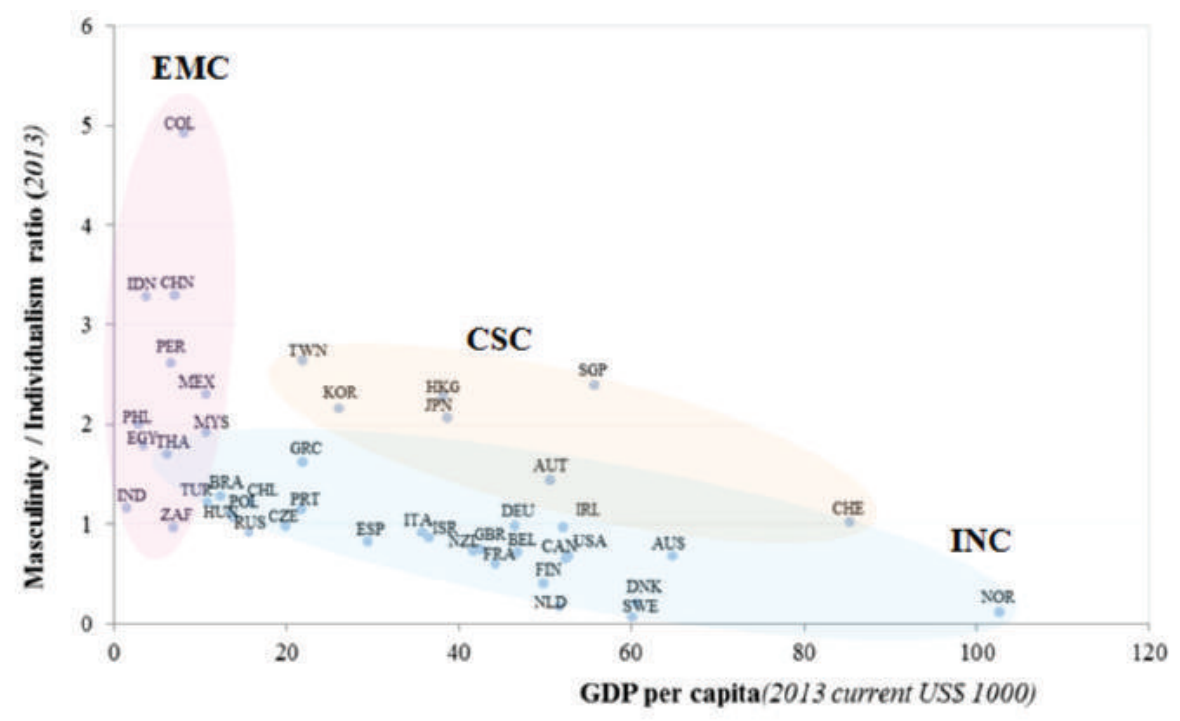

Figure 7: Econo-cultural Dimension of 44 Countries (2013). 
With such observation, Fig. 8 correlates cultural dimension by means of masculinity/individualism ratio and GBI. This correlation demonstrates statistical significance as demonstrated in Table 3.

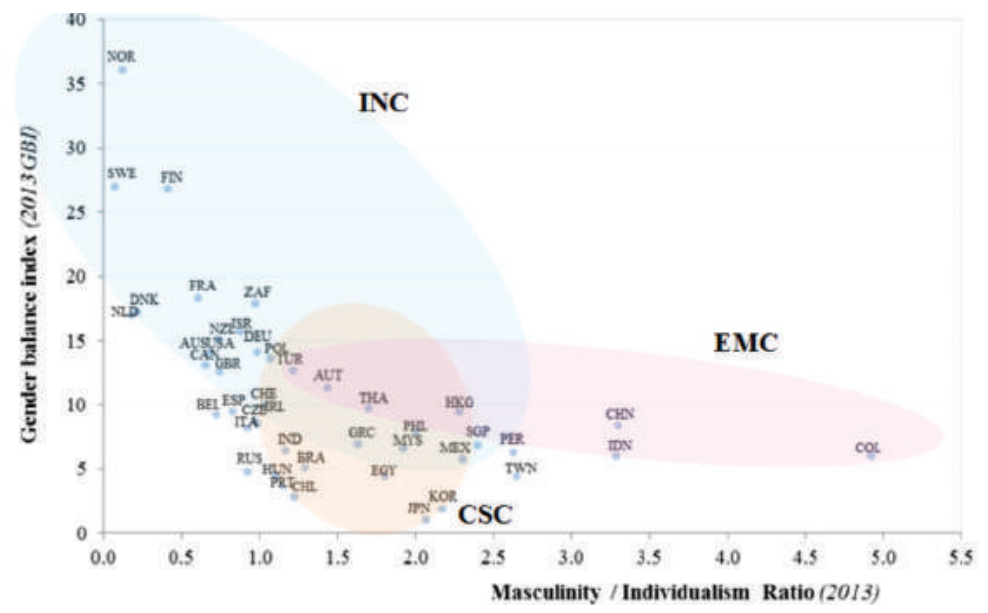

Figure 8: Correlation between Cultural Dimension and Gender Balance Index in 44 Countries (2013).

Table 3: Correlation between Cultural Dimension and Gender Balance.
Harnessing Women's Potential as a Soft Engine

$Y$ : Gender Balance Index, $M / I$ : Cultural dimension index (ratio of masculinity and individualism),

$D_{l}, D_{2}$ and $D_{3}$ : Coefficient dummy variables corresponding to EMC, INC and CSC, respectively.

$D_{C}$ and $D_{S}$ : Dumy variables $(\mathrm{CHL}=1$, others $=0$ and $\mathrm{SGP}=1$, others $=0$, respectively).

The figures in parenthesis indicate $t$-statistics: all are significant at the $1 \%$ level except $* 4 \%$

These analyses support the preceding classification of GBI intensity in 44 countries including CSC with unique cultural dimension as SGP, CHE, KOR and JPN (see Appendix 3).

\section{GENDER BALANCED LEADERSHIP IN DIGITAL ECONOMY \\ Co-evolution between Economic Growth, Gender Balance and ICT Advancement}

With the understanding that harnessing the vigor of women potential by improving gender balance is essential for inclusive economic growth in the 
Watanabe, $\mathrm{C}$. Naveed, K.

Neittaanmäki, P. digital economy, following the findings obtained in the preceding Section, trilateral co-evolution between economic growth, gender balance improvement and ICT advancement was analyzed by using GBI (gender balance index) and also based on the classification of EMC, INC and CSC.

Fig. 9 illustrates dynamism inducing this trilateral co-evolution.

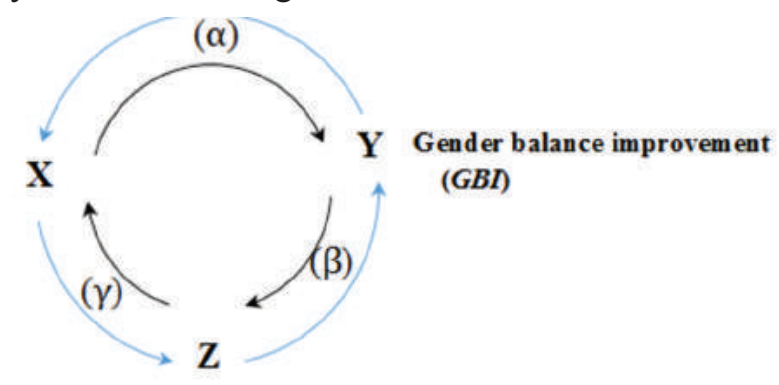

ICT Advancement

(NRI)

Figure 9: Co-evolutionary Dynamism between Income Level, Gender Balance Improvement and ICT Advancement.

NRI: Networked Readiness Index

$\alpha$ : X elasticity to $Y, \beta$ : Y elasticity to $Z, \gamma: Z$ elasticity to $X$.

\section{Gender Balance Improvement Induced by Economic Growth}

Fig. 10 illustrates correlation between GDP per capita and gender balance index which demonstrates statistical significance. EMC demonstrates highest elasticity of GDP per capita to gender balance improvement followed by INC and CSC. This suggests EMC expects significant improvement of gender balance once it succeeds to economic growth.

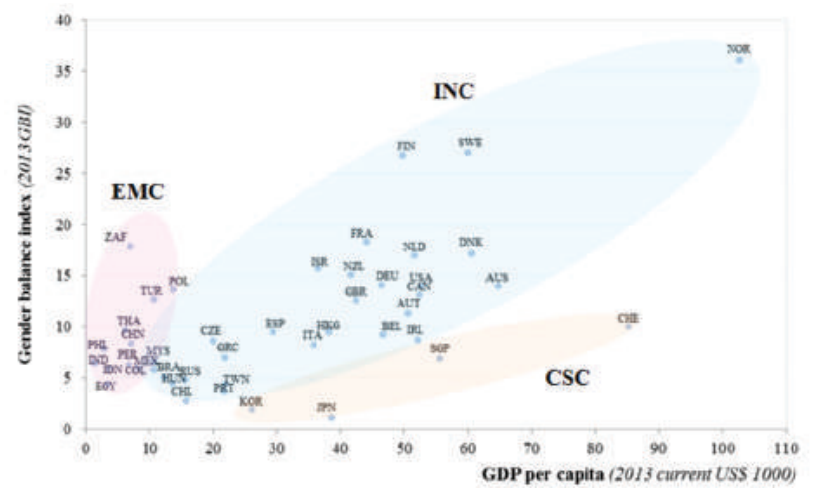

Figure 10: Correlation between GDP per Capita and Gender Balance Index in 44 Countries (2013). 
$\ln Y=-4.929+0.817 D_{1} \ln X+0.696 D_{2} \ln X+0.608 D_{3} \ln X-1.393 D \quad$ adj. $R 2 \quad 0.659$ $(-4.91)$

$Y$ : Gender Balance Index, $X$ : GDP per capita, $D_{l}, D_{2}$ and $D_{3}$ : Coefficient dummy variables corresponding to EMC, INC and CSC, respectively.

$D$ : Dummy variable $(\mathrm{JPN}=1$, others $=0)$.

The figures in parenthesis indicate $t$-statistics: all are significant at the $1 \%$ level

\section{ICT Advancement Stimulated by Gender Balance Improvement}

Fig. 11 illustrates correlation between gender balance index and ICT advancement which also demonstrates statistical significance. INC demonstrates highest elasticity of gender balance improvement to ICT advancement followed by CSC and EMC. This suggests EMC necessitates dramatic advancement in women's ICT involvement as increase in women's contribution to ICT advancement through their effective ICT utilization and development.

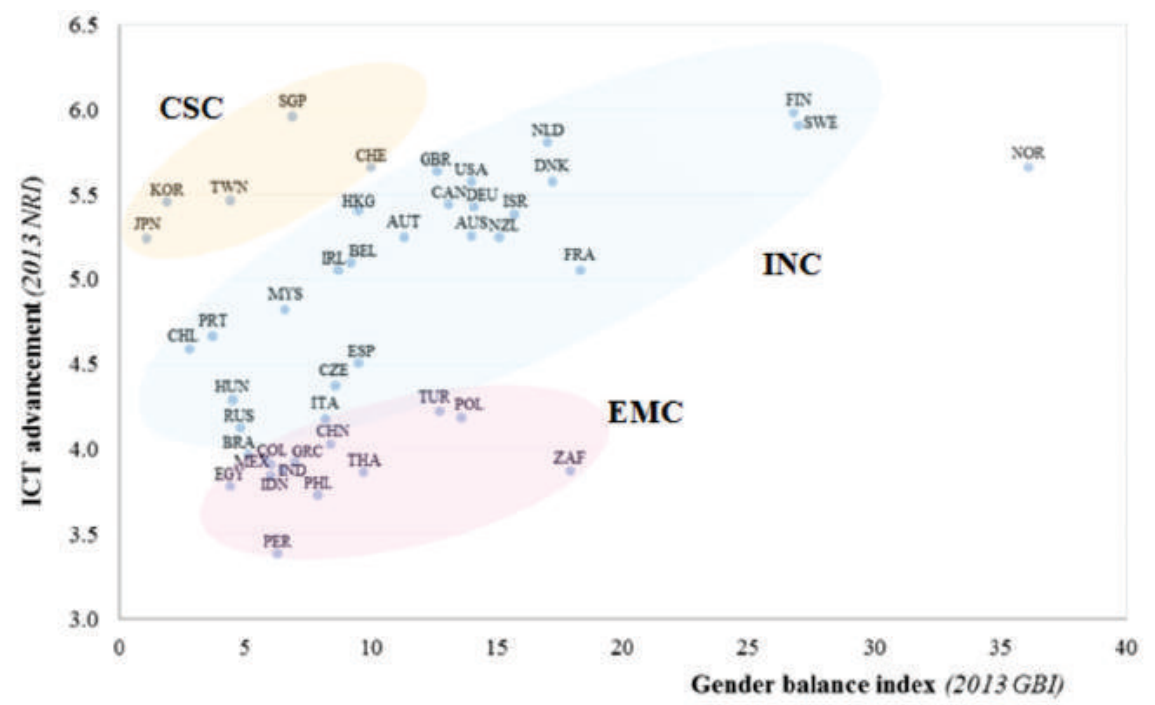

Figure 11: Correlation between Gender Balance Index and ICT Advancement in 44 Countries (2013).

$$
\begin{array}{cccc}
\ln Z= & 1.227+0.061 D_{1} \ln Y+0.162 D_{2} \ln Y+0.089 D_{3} \ln Y+0.351 D_{\square} \\
(23.16) & \left(2.30^{*}\right) & (7.19) & \left(2.39^{*}\right)
\end{array}
$$

adj. $R^{2} \quad 0.771$

$D_{1}, D_{2}$ and $D_{3}$ : Coefficient dummy variables corresponding to EMC, INC and CSC, respectively.

$D$ : Dummy variable $(C H E, J P N, K O R, S G P, T W N=1$, others $=0)$. 
Watanabe, C. The figures in parenthesis indicate $t$-statistics: all are significant at the $1 \%$ Naveed, K. level except $* 2 \%$.

Neittaanmäki, P. NOR is not included in the analysis.

\section{ICT Advancement Stimulated by Gender Balance Improve}

Fig. 12 illustrates correlation between ICT advancement and GDP per capita which also demonstrates statistical significance. INC demonstrates highest elasticity of ICT advancement to GDP per capita increase followed by CSC with almost similar level. EMC behinds two groups. This suggests EMC necessitates further improvement in introduction and utilization of ICT.

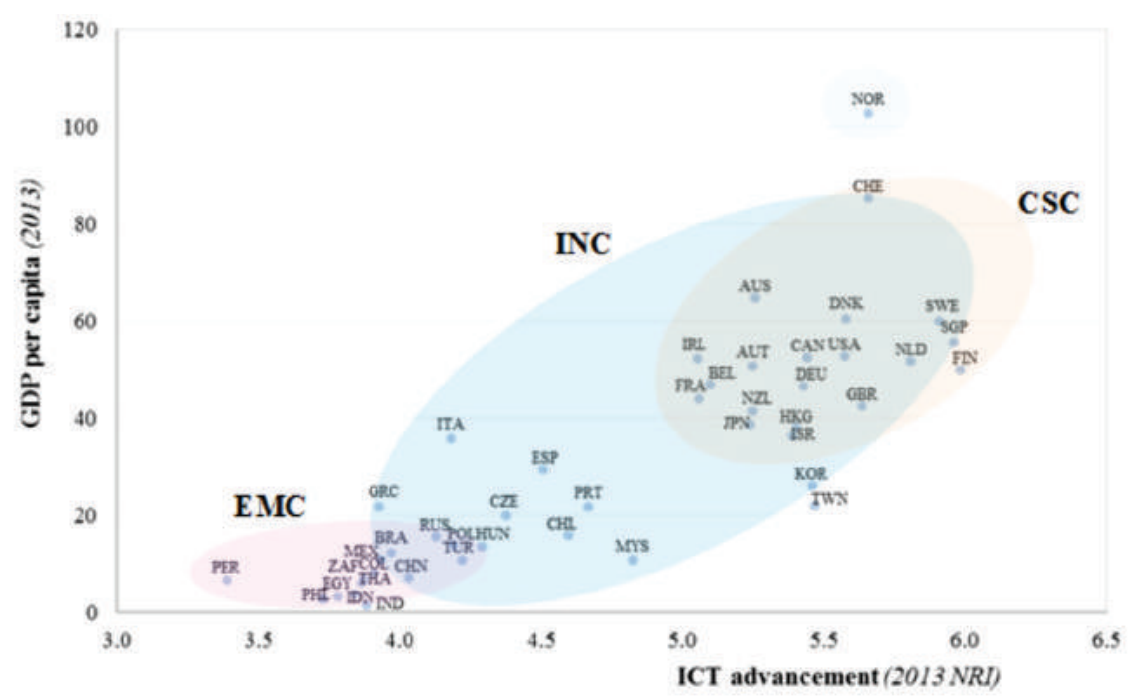

Figure 12: Correlation between ICT Advancement and GDP per Capita in 44 Countries (2013).

$$
\begin{aligned}
& \ln X=4.631+3.028 D_{1} \ln Z+3.579 D_{2} \ln Z+3.564 D_{3} \ln Z \quad \text { adj. } \boldsymbol{R}^{2} \quad 0.815 \\
& \text { (5.30) (4.66) }
\end{aligned}
$$

The figures in parenthesis indicate $t$-statistics: all are significant at the $1 \%$ level

$X$ : GDP per capita, $Z$ : ICT advancement,

$D_{1}, D_{2}$ and $D_{3}$ : Coefficient dummy variables corresponding to EMC, INC and $\mathrm{CSC}$, respectively.

The figures in parenthesis indicate $t$-statistics: all are significant at the $1 \%$ level

NOR is not included in the analysis. 


\section{CONSEQUENCE OF CO-EVOLUTIONARY DYNAMISM}

Table 4 summarizes elasticities of trilateral co-evolution.

Looking at Table 4 we note that while EMC demonstrates highest level of elasticity of GDP per capita to gender balance improvement ( $\alpha$ ), due to extremely low level of elasticity of gender balance improvement to ICT advancement $(\beta)$, its performance of trilateral co-evolution $(\alpha \beta \gamma)$ results in the extreme low level. Contrary to such low performance in EMC, INC demonstrates explicit performance in its trilateral co-evolution. This can be attributed to its outperformed elasticity of gender balance improvement to ICT advancement. Finland which stands the leading position in INC with the highest GBI intensity as demonstrated in Fig. 6 may provide insightful suggestion for increasing this elasticity.

Table 4: Elasticities of Co-evolution in 44 Countries (2013)

\begin{tabular}{|l|c|c|c|c|}
\hline & $\boldsymbol{\alpha}$ & $\boldsymbol{\beta}$ & $\boldsymbol{\gamma}$ & $\boldsymbol{\alpha} \boldsymbol{\beta} \boldsymbol{\gamma}$ \\
\hline $\boldsymbol{E M C}$ & 0.817 & 0.061 & 3.028 & 0.151 \\
\hline $\boldsymbol{I N C}$ & 0.696 & 0.162 & 3.579 & 0.404 \\
\hline $\boldsymbol{C S C}$ & 0.608 & 0.089 & 3.564 & 0.193 \\
\hline
\end{tabular}

Considering the significance of elasticity of gender balance improvement to ICT advancement () for advancing the performance of trilateral co-evolution, Fig. 13 compares women's dependency on the Internet use. As anticipated EMC demonstrates extremely low level of this dependency (half level of other 2 groups). This fact suggests the significance of lessons from success countries for improving women's further initiative in involvement in ICT development and utilization.

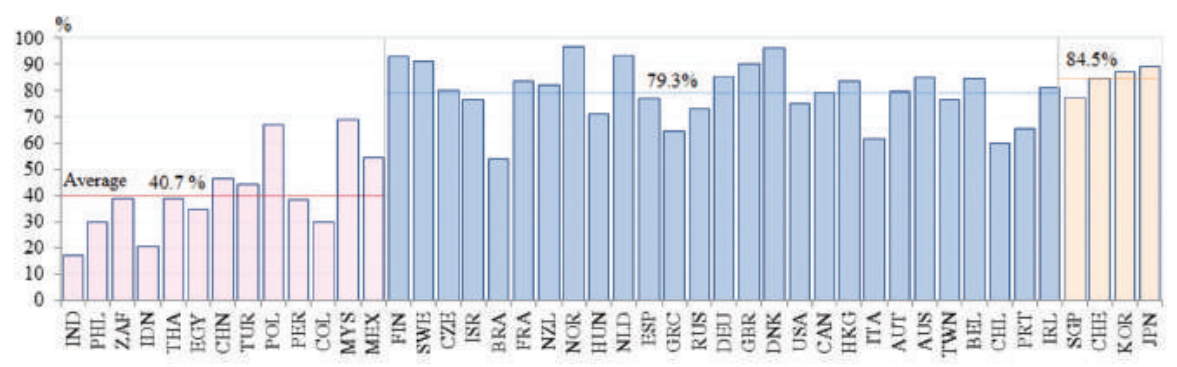

Figure 13: Percentage of Women Using the Internet in 44 Countries (2013). Source: ITU (2014).
Harnessing

Women's

Potential as a

Soft Engine 
Watanabe, $\mathrm{C}$. Naveed, K.

Neittaanmäki, P.

\section{LESSONS FROM CONTRASTING TRAJECTORIES BETWEEN FINLAND AND JAPAN}

As reviewed in the preceding Section, it is essential for emerging countries to have extensive lessons from success and failure on ICT advancement with relevance to gender balanced organization leadership. In this context, Finland and Japan which demonstrate contrasting trajectories in this leadership can be considered good examples of success and failure.

With this in mind, Table 5 demonstrate contrast between Finland and Japan in gender balanced organization leadership.

Table 5: Contrast between Finland and Japan in Gender Balanced

Organization Leadership

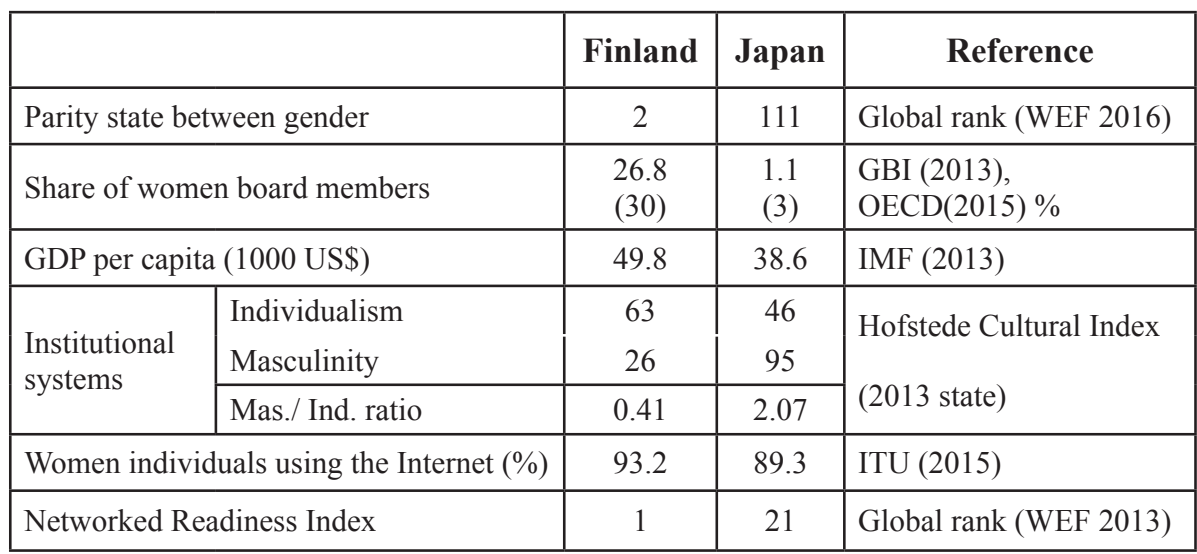

Based on this contrasting structure, institutional sources leading to contrasting trajectories with respect to women's leadership in two countries were analyzed.

Table 6 and Fig. 14 demonstrate trends in women Directors share in both countries over the period 2001-2016.

Table 6: Trends in Women Directors Share in Finland and Japan (2001-2016) - \%

Finland

\begin{tabular}{|c|c|c|c|c|c|c|c|c|c|c|c|c|c|c|c|}
\hline $\mathbf{2 0 0 1}$ & $\mathbf{2 0 0 2}$ & $\mathbf{2 0 0 3}$ & $\mathbf{2 0 0 4}$ & $\mathbf{2 0 0 5}$ & $\mathbf{2 0 0 6}$ & $\mathbf{2 0 0 7}$ & $\mathbf{2 0 0 8}$ & $\mathbf{2 0 0 9}$ & $\mathbf{2 0 1 0}$ & $\mathbf{2 0 1 1}$ & $\mathbf{2 0 1 2}$ & $\mathbf{2 0 1 3}$ & $\mathbf{2 0 1 4}$ & $\mathbf{2 0 1 5}$ & $\mathbf{2 0 1 6}$ \\
\hline 5.0 & 6.0 & 7.0 & 8.5 & 10.5 & 12.0 & 13.5 & 15.0 & 16.0 & 18.0 & 19.0 & 21.5 & 22.5 & 23.0 & 24.0 & 25.0 \\
\hline
\end{tabular}

\section{Japan}

\begin{tabular}{|c|c|c|c|c|c|c|c|c|c|c|c|c|c|c|c|}
\hline $\mathbf{2 0 0 1}$ & $\mathbf{2 0 0 2}$ & $\mathbf{2 0 0 3}$ & $\mathbf{2 0 0 4}$ & $\mathbf{2 0 0 5}$ & $\mathbf{2 0 0 6}$ & $\mathbf{2 0 0 7}$ & $\mathbf{2 0 0 8}$ & $\mathbf{2 0 0 9}$ & $\mathbf{2 0 1 0}$ & $\mathbf{2 0 1 1}$ & $\mathbf{2 0 1 2}$ & $\mathbf{2 0 1 3}$ & $\mathbf{2 0 1 4}$ & $\mathbf{2 0 1 5}$ & $\mathbf{2 0 1 6}$ \\
\hline 3.6 & 4.5 & 4.6 & 5.0 & 5.1 & 5.8 & 6.5 & 6.6 & 7.2 & 7.0 & 8.1 & 8.5 & 8.9 & 9.4 & 9.8 & 10.3 \\
\hline
\end{tabular}

Sources: The $6^{\text {th }}$ Women Directors and Executives Report 2016 (FINNCHAM, 2016) for Finland, and Health, Labor and Welfare White Paper in Japan (Ministry of Health, Labor and Welfare of Japan, 2013) for Japan with complemental estimates (see original sources Appendix 4).

Journal of Technology Management for Growing Economies, Volume 8, Number 1, April 2017 


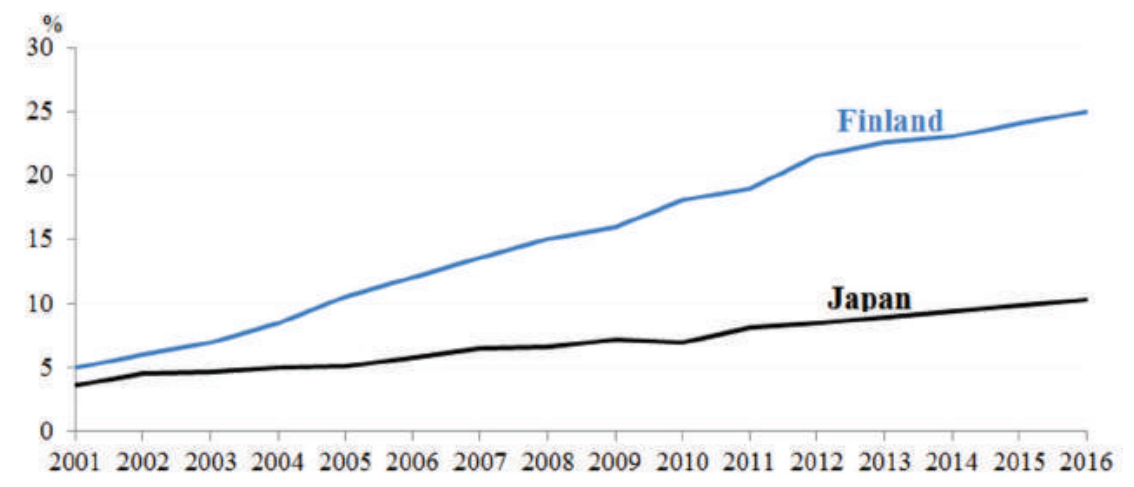

Harnessing

Women's

Potential as a

Soft Engine

Figure 14: Trends in Women Directors Share in Finland and Japan

$$
\text { (2001-2016) - \%. }
$$

Sources: The $6^{\text {th }}$ Women Directors and Executives Report 2016 (FINNCHAM, 2016) for Finland, and Health, Labor and Welfare White Paper in Japan (Ministry of Health, Labor and Welfare of Japan, 2013) for Japan with complemental estimates (see original sources Appendix 4).

Based on these trajectories, incorporation of self-propagating function in two countries in their gender balance improvement trajectories was examined. Since self-propagating function can be considered core function of ICT (Watanabe et al., 2017a, 2017b), incorporation of this function demonstrates that gender balance improvement has been accomplished by utilizing ICT advancement effectively and thus this function could be the sources of higher elasticity of gender balance improvement to ICT advancement as demonstrated in INC in which Finland plays leading role.

With the understanding that this self-propagating function can be attributed to its adaptability to logistic growth within a dynamic carrying capacity (LGDCC) function rather than simple logistic growth (SLG) (Watanabe et al., 2004), fitness of two countries trajectories to LGDCC was compared.

Table 7: Comparison of Self-propagating Function Incorporating in Finland and Japan (2001-2016)

$$
\text { LGDCC } \quad Y(t)=\frac{N_{k}}{1+b e^{-a t}+\frac{b_{k}}{1-\frac{a_{a}}{a}} e^{-a_{k} t}}
$$

\begin{tabular}{|c|c|c|c|c|c|c|c|}
\hline \multirow[t]{2}{*}{ Finland } & SLG & $\begin{array}{c}28.60 \\
(32.31)\end{array}$ & $\begin{array}{c}0.23 \\
(17.63)\end{array}$ & $\begin{array}{c}1.06 \\
(28.60)\end{array}$ & & & 0.996 \\
\hline & LGDCC & $\begin{array}{l}44.84 \\
(8.57)\end{array}$ & $\begin{array}{c}0.29 \\
(88.90)\end{array}$ & $\begin{array}{c}3.91 \\
(7.34)\end{array}$ & $0.05(5.15)$ & $\begin{array}{c}1.11 \\
(5.33)\end{array}$ & 0.999 \\
\hline \multirow[t]{2}{*}{ Japan } & SLG & $\begin{array}{l}18.15 \\
(4.11)\end{array}$ & $\begin{array}{c}0.10 \\
(5.59)\end{array}$ & $\begin{array}{c}2.95 \\
(3.57)\end{array}$ & & & 0.990 \\
\hline & LGDCC & $\begin{array}{l}21.41 \\
(0.03)^{\#}\end{array}$ & $\begin{array}{c}0.14 \\
(0.02)^{\#}\end{array}$ & $\begin{array}{c}1.45 \\
(0.003) \text { \# }\end{array}$ & $\begin{array}{c}0.07(0.01) \\
\#\end{array}$ & $\begin{array}{c}1.07 \\
(0.01)^{\#}\end{array}$ & 0.990 \\
\hline
\end{tabular}


Watanabe, $\mathrm{C}$.

Naveed, K.

Neittaanmäki, P.

84

$Y$ : Women directors share (\%): $N_{k}$ : carrying capacity; $t$ : time; $a, b, a_{k}, b_{k}$ : coefficients.

Figures in parenthesis indicate t-statistics: significant at the $1 \%$ level except ${ }^{\#}$ : in-significant level.

Table 7 summarizes this comparison which demonstrates that while Finland demonstrates fitting to LGDCC, Japan fits to simple logistic growth (SLG) without such self-propagating function. Based on this analysis, Fig. 15 estimates prospects of women Directors share in Finland and Japan.

Fig. 15 suggests that while women Directors share remains $18 \%$ in Japan, Finland can expect to such high level as $45 \%$. This high level can be attributed to its incorporation of self-propagating function without which the level would remain $29 \%$.

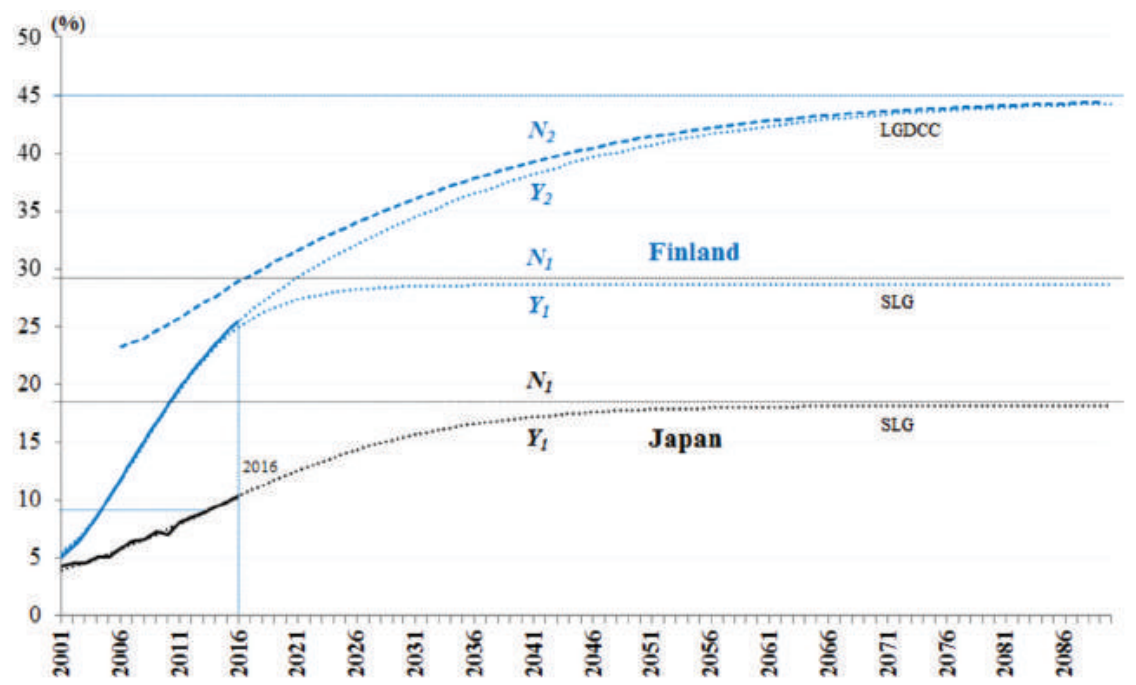

Figure 15: Trends and Prospects of Women Directors Share in Finland and

$$
\text { Japan - \%. }
$$

$Y_{l}$ : Trajectory without self-propagating function. $Y_{2}$ : Trajectory with self-propagating function. $N_{l}$ : Carrying capacity in SLG. $N_{2}$ : Carrying capacity in LGDCC.

This contrast suggests the significance of self-propagating function for sustainable gender balance improvement in the digital economy.

\section{CONCLUSION}

In light of the increasing significance of harnessing the vigor of women potential in the digital economy moving toward aging society, an empirical numerical analysis focusing on trilateral co-evolution between economic growth, gender balance improvement and ICT advancement taking cultural dimensions into account in 44 countries was attempted. Furthermore, aiming at providing emerging countries lessons of success and failure in advanced

Journal of Technology Management for Growing Economies, Volume 8, Number 1, April 2017 
countries, comparative analysis on the gender balance improvement trajectories in Finland and Japan was conducted.

Noteworthy findings include:

(i) Gender balance improvement can be monitored by gender balance index based on the share of women on board which represents parity state between gender.

(ii) Gender balance intensity could be effective supportive tool in identifying the state of gender balance improvement.

(iii) Gender balance improvement is subject to cultural dimensions, particularly to muscularity and individualism.

(iv) Gender balance intensity level in 44 countries can be classified into emerging countries (EMC), industrialized countries (INC) and countries with specific culture (CSC).

(v) INC demonstrates explicit performance in triple co-evolution between economic growth, gender balance improvement and ICT advancement.

(vi) This explicit performance can be attributed to its high level of elasticity of gender balance improvement to ICT advancement.

(vii)EMC remains extremely low level of this elasticity resulting in the lowest performance in triple co-evolution not withstanding highest elasticity of growth to gender balance improvement.

(viii)Finland demonstrates conspicuous performance in this co-evolution based on a self-propagating function in gender balance improvement trajectory while Japan was unable to incorporate this function due primarily to its male-dominated culture.

These findings give rise to insightful suggestions to respective countries about their successful trilateral co-evolution:

(i) Realize the significance of harnessing the vigor of sleeping resources incorporated in women's potential.

(i) Recognize clear link chain between women board member share corporate performance - gender quality in the workplace - gender quality in society.

(ii) Accelerate the last decade of activism to smash the glass ceiling in triggering to constructing the link chain.

(iii) Utilize gender balance intensity in managing gender balance improvement.

(iv) Improve cultural dimensions impeding gender balance improvement efforts.

(v) Every effort should focus on the construction of trilateral co-evolution.

(vi) Effective development and utilization of ICT should be the highest priority
Harnessing

Women's

Potential as a

Soft Engine 
Watanabe, C. Naveed, K.

Neittaanmäki, P. for EMC in constructing trilateral co-evolution.

(vii)For this, construction of self-propagating function should be challenged with the highest priority.

(viii)Reconstruction of male-dominated society should be the focal challenge for CSC

This paper explored a new systematic approach for improving gender balance 86 by means of triple co-evolution between economic growth, gender balance improvement and ICT advancement.

This study focused on c-evolution between economic growth, gender balance improvement and digital innovation initiated by ICT advancement taking into account of "masculinity" and "individualism" as cultural dimension. The other factors like work culture, effects of tradition and political factors still remain unexplored.

Further work should focus on complementing unexplored analysis as well as in-depth analysis of success and failure trajectories with respect to gender balance improvement. Analyses of success and failure cases should be enriched. 


\section{APPENDIX}

\section{Appendix 1: Institutional State of 44 Countries Analyzed}

Table A1 State of Gender Balance, Cultural Dimension and Internet Usage in 44 Countries (2013)

\begin{tabular}{|c|c|c|c|c|c|c|c|c|}
\hline \multirow[b]{2}{*}{ Country } & \multirow{2}{*}{$\begin{array}{l}\text { Coun- } \\
\text { try } \\
\text { Code }\end{array}$} & \multirow{2}{*}{$\begin{array}{c}\text { Gender } \\
\text { Bal- } \\
\text { ance } \\
\text { Index } \\
\text { (GBI) }\end{array}$} & \multirow{2}{*}{$\begin{array}{l}\text { GDP per } \\
\text { capita } \\
\text { (current } \\
\text { US\$) }\end{array}$} & \multirow{2}{*}{$\begin{array}{l}\text { GBI intensity } \\
\text { (GBI/GDP per } \\
\text { capita x1000) }\end{array}$} & \multicolumn{3}{|c|}{ Cultural dimension* } & \multirow{2}{*}{$\begin{array}{c}\text { Women } \\
\text { Internet } \\
\text { usage } \\
(\%)\end{array}$} \\
\hline & & & & & Ind. & Mas. & $\begin{array}{l}\text { Mas/ } \\
\text { Ind } \\
\text { ratio }\end{array}$ & \\
\hline Norway & NOR & 36.1 & 102,564 & 0.35 & 69 & 8 & 0.12 & 96.7 \\
\hline Sweden & SWE & 27.0 & 60,005 & 0.45 & 71 & 5 & 0.07 & 91.1 \\
\hline Finland & FIN & 26.8 & 49,766 & 0.54 & 63 & 26 & 0.41 & 93.2 \\
\hline France & FRA & 18,3 & 44,105 & 0.41 & 71 & 43 & 0.61 & 83.7 \\
\hline South Africa & ZAF & 17.9 & 6,914 & 2.59 & 65 & 63 & 0.97 & 39.0 \\
\hline Denmark & DNK & 17.2 & 60,494 & 0.28 & 74 & 16 & 0.22 & 96.4 \\
\hline Netherlands & NLD & 17.0 & 51,595 & 0.33 & 80 & 14 & 0.18 & 93.5 \\
\hline Israel & ISR & 15.7 & 36,410 & 0.43 & 54 & 47 & 0.87 & 76.3 \\
\hline $\begin{array}{l}\text { New Zea- } \\
\text { land }\end{array}$ & NZL & 15.1 & 41,555 & 0.36 & 79 & 58 & 0.73 & 82.2 \\
\hline Germany & DEU & 14.1 & 46,475 & 0.30 & 67 & 66 & 0.99 & 85.5 \\
\hline Australia & AUS & 14.0 & 64,664 & 0.22 & 90 & 61 & 0.68 & 84.9 \\
\hline USA & USA & 14.0 & 52,705 & 0.27 & 91 & 62 & 0.68 & 75.0 \\
\hline Poland & POL & 13.6 & 13,773 & 0.99 & 60 & 64 & 1.07 & 66.9 \\
\hline Canada & CAN & 13.1 & 52,345 & 0.25 & 80 & 52 & 0.65 & 79.2 \\
\hline Turkey & TUR & 12.7 & 10,761 & 1.18 & 37 & 45 & 1.22 & 44.0 \\
\hline UK & GBR & 12.6 & 42,453 & 0.30 & 89 & 66 & 0.74 & 90.4 \\
\hline Austria & AUT & 11.3 & 50,585 & 0.22 & 55 & 79 & 1.44 & 79.7 \\
\hline Switzerland & CHE & 10.0 & 85,237 & 0.12 & 68 & 70 & 1.03 & 84.3 \\
\hline Thailand & THA & 9.7 & 6,148 & 1.58 & 20 & 34 & 1.70 & 38.9 \\
\hline Hong Kong & $\mathrm{HKG}$ & 9.5 & 38,170 & 0.25 & 25 & 57 & 2.28 & 83.3 \\
\hline Spain & ESP & 9.5 & 29,397 & 0.32 & 51 & 42 & 0.82 & 77.1 \\
\hline Belgium & BEL & 9.2 & 46,726 & 0.20 & 75 & 54 & 0.72 & 84.3 \\
\hline Ireland & IRL & 8.7 & 52,094 & 0.17 & 70 & 68 & 0.97 & 81.2 \\
\hline $\begin{array}{l}\text { Czech } \\
\text { Republic }\end{array}$ & $\mathrm{CZE}$ & 8.6 & 19,913 & 0.43 & 58 & 57 & 0.98 & 80.1 \\
\hline China & $\mathrm{CHN}$ & 8.4 & 7,081 & 1.19 & 20 & 66 & 3.30 & 46.4 \\
\hline Italy & ITA & 8.2 & 35,704 & 0.23 & 76 & 70 & 0.92 & 61.7 \\
\hline Philippines & PHL & 7.9 & 2,769 & 2.85 & 32 & 64 & 2.00 & 30.0 \\
\hline Greece & GRC & 7.0 & 21,773 & 0.32 & 35 & 57 & 1.63 & 64.5 \\
\hline
\end{tabular}

Journal of Technology Management for Growing Economies, Volume 8, Number 1, April 2017
Harnessing

Women's

Potential as a

Soft Engine

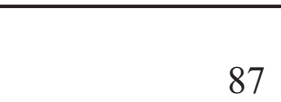


Watanabe, $\mathrm{C}$.

Naveed, K.

Neittaanmäki, P.

\begin{tabular}{|l|l|l|r|r|r|r|r|l|}
\hline Singapore & SGP & 6.9 & 55,617 & 0.12 & 20 & 48 & 2.40 & 77.3 \\
\hline Malaysia & MYS & 6.6 & 10,700 & 0.62 & 26 & 50 & 1.92 & 69.0 \\
\hline India & IND & 6.5 & 1,480 & 4.39 & 48 & 56 & 1.17 & 17.0 \\
\hline Peru & PER & 6.3 & 6,626 & 0.95 & 16 & 42 & 2.63 & 38.5 \\
\hline Columbia & COL & 6.0 & 8,068 & 0.74 & 13 & 64 & 4.92 & 30.0 \\
\hline Indonesia & IDN & 6.0 & 3,676 & 1.63 & 14 & 46 & 3.29 & 20.3 \\
\hline Mexico & MEX & 5.8 & 10,659 & 0.54 & 30 & 69 & 2.30 & 54.6 \\
\hline Brazil & BRA & 5.1 & 12,260 & 0.42 & 38 & 49 & 1.29 & 54.2 \\
\hline Russia & RUS & 4.8 & 15,559 & 0.31 & 39 & 36 & 0.92 & 73.0 \\
\hline Hungary & HUN & 4.5 & 13,564 & 0.33 & 80 & 88 & 1.10 & 71.2 \\
\hline Taiwan & TWN & 4.4 & 21,888 & 0.20 & 17 & 45 & 2.65 & 76.3 \\
\hline Egypt & EGY & 4.4 & 3,374 & 1.30 & 25 & 45 & 1.80 & 34.8 \\
\hline Portugal & PRT & 3.7 & 21,626 & 0.17 & 27 & 31 & 1.15 & 65.7 \\
\hline Chile & CHL & 2.8 & 15,714 & 0.18 & 23 & 28 & 1.22 & 60.0 \\
\hline $\begin{array}{l}\text { Korea } \\
\text { (Rep.) }\end{array}$ & KOR & 1.9 & 25,998 & 0.07 & 18 & 39 & 2.17 & 87.1 \\
\hline Japan & JPN & 1.1 & 38,552 & 0.03 & 46 & 95 & 2.07 & 89.3 \\
\hline
\end{tabular}

*Ind. : Individualism, Mas.: Masculinity.

Original sources: GMI Ratings (2013), IMF (2014), Geert Hofstede (2014), ITU (2014).

\section{Appendix 2 Concept of Masculinity and Individualism}

Masculinity versus its opposite, femininity, refers to the distribution of roles between the genders which is another fundamental issue for any society to which a range of solutions are found. The IBM studies revealed that (a) women's values differ less among societies than men's values; (b) men's values from one country to another contain a dimension from very assertive and competitive and maximally different from women's values on the one side, to modest and caring and similar to women's values on the other. The assertive pole has been called 'masculine' and the modest, caring pole 'feminine'. The women in feminine countries have the same modest, caring values as the men; in the masculine countries they are somewhat assertive and competitive, but not as much as the men, so that these countries show a gap between men's values and women's values.

Individualism on the one side versus its opposite, collectivism, that is the degree to which individuals are integrated into groups. On the individualist side we find societies in which the ties between individuals are loose: everyone is expected to look after him/herself and his/her immediate family. On the collectivist side, we find societies in which people from birth onwards are integrated into strong, cohesive in-groups, often extended families (with uncles, aunts and grandparents) which continue protecting them in exchange 
for unquestioning loyalty. The word 'collectivism' in this sense has no political meaning: it refers to the group, not to the state. Again, the issue addressed by this dimension is an extremely fundamental one, regarding all societies in the world. Source: Hofstede (1991).
Harnessing Women's Potential as a Soft Engine

\section{Appendix 3 Intensified Masculinity Density - Intensified Male-dominated Society}

Intensified male-dominated society (IMS) can be estimated by the ratio of "masculinity" and "individualism intensity" as follows where individualism intensity is the ratio of "individualism" and income level.

$\mathrm{IMS}=\frac{M}{I / G D P \text { per capita }}=\frac{M}{I} \cdot G D P$ pr capita where M: Masculinity, I: Individualism

\section{M/I Ratio*GDPperCapita_1000USD}

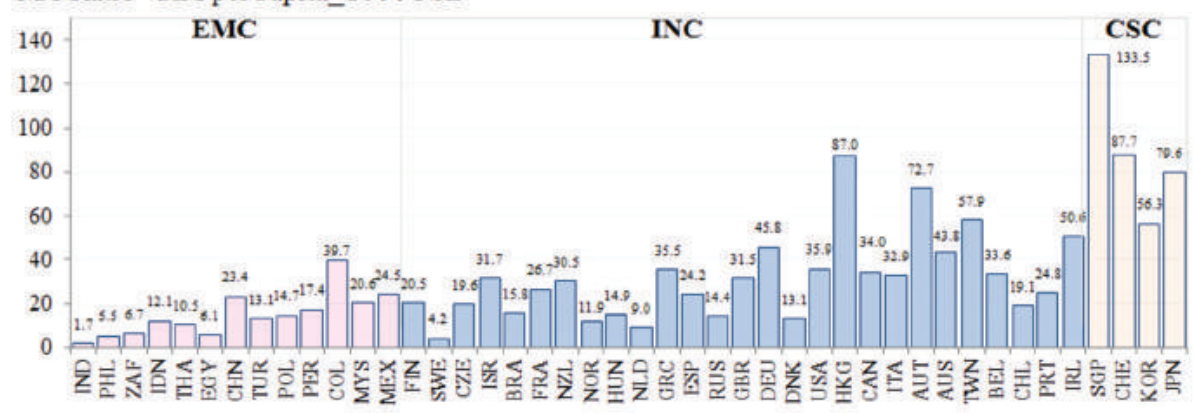

Figure A1: Intensified Masculinity Density (Intensified Male-dominated Society: IMS) in 44 Countries (2013).

Countries of CSC demonstrate high "intensified Masculinity density" (highly intensified male-dominated society).

IMS has significant correlation with Gender Balance Intensity as follows which endorses the reasonability of the classification of EMC, INC and CSC:

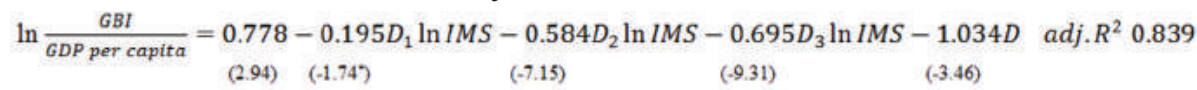
where $D_{l}-D_{3}$ and $D$ are dummy variables. $D_{1}: \mathrm{EMC}=1$, others $=0 ; D_{2}: \mathrm{INC}=0$, others $=0 ; D_{3}: \mathrm{CSC}=1$, others $=0$; $D:$ JPN and $\mathrm{CHL}=1$, others $=0$.

The figures in parenthesis indicate t-statistics: all are significant at the $1 \%$ level except $* 10 \%$.

\section{APPENDIX 4 DATA CONSTRUCTION}

Table A2: Trends in Women Directors Share in Finland and Japan (19189-

$$
\text { 2016) }-\%
$$

Complementary estimates were conducted based on respective original 
Watanabe, $\mathrm{C}$. Naveed, K.

Neittaanmäki, P.

estimate taking into account of OECD and WEF surveys and utilizing data from EC and EMI Rating.

Finland

\begin{tabular}{|r|r|r|r|r|r|r|r|r|r|r|r|r|r|r|r|}
\hline $\mathbf{2 0 0 1}$ & $\mathbf{2 0 0 2}$ & $\mathbf{2 0 0 3}$ & $\mathbf{2 0 0 4}$ & $\mathbf{2 0 0 5}$ & $\mathbf{2 0 0 6}$ & $\mathbf{2 0 0 7}$ & $\mathbf{2 0 0 8}$ & $\mathbf{2 0 0 9}$ & $\mathbf{2 0 1 0}$ & $\mathbf{2 0 1 1}$ & $\mathbf{2 0 1 2}$ & $\mathbf{2 0 1 3}$ & $\mathbf{2 0 1 4}$ & $\mathbf{2 0 1 5}$ & $\mathbf{2 0 1 6}$ \\
\hline 5.0 & 6.0 & 7.0 & 8.5 & 10.5 & 12.0 & 13.5 & 15.0 & 16.0 & 18.0 & 19.0 & 21.5 & 22.5 & 23.0 & 24.0 & 25.0 \\
\hline
\end{tabular}

Original source: The $6^{\text {th }}$ Women Directors and Executives Report 2016 (FINNCHAM, 2016).

Values indicated by blue are based on complemental estimates utilizing FINNCHAM and EC Report on equality between women and men in the EU.

Japan

\begin{tabular}{|c|c|c|c|c|c|c|c|c|c|c|c|c|c|}
\hline 1989 & 1990 & 1991 & 1992 & 1993 & 1994 & 1995 & 1996 & 1997 & 1998 & 1999 & 2000 & 2001 & 2002 \\
\hline 2.0 & 2.0 & 2.3 & 2.9 & 2.5 & 2.6 & 2.8 & 3.1 & 3.7 & 3.2 & 3.4 & 4.0 & 3.6 & 4.5 \\
\hline 2003 & 2004 & 2005 & 2006 & 2007 & 2008 & 2009 & 2010 & 2011 & 2012 & 2013 & 2014 & 2015 & 2016 \\
\hline 4.6 & 5.0 & 5.1 & 5.8 & 6.5 & 6.6 & 7.2 & 7.0 & 8.1 & 8.5 & 8.9 & 9.4 & 9.8 & 10.3 \\
\hline
\end{tabular}

Original source: Health, Labor and Welfare White Paper in Japan (Ministry of Health, Labor and Welfare of Japan, 2013).

Values indicated by blue are based on complemental estimates utilizing GMI Rating data.

\section{APPENDIX 5 DYNAMISM IN EMERGING SELF-PROPAGATING FUNCTION}

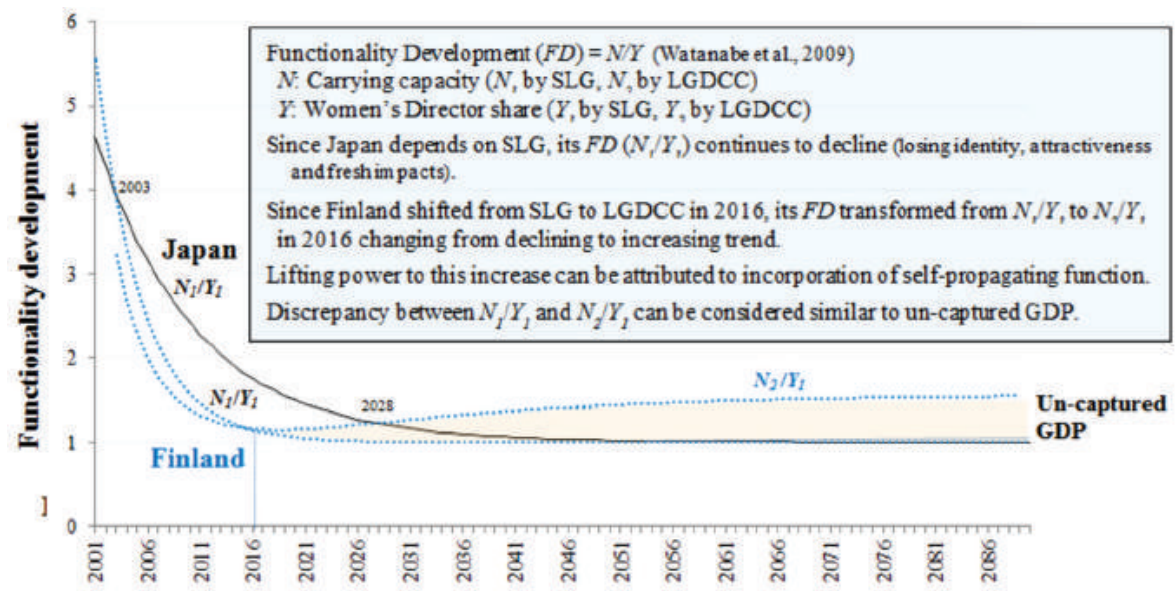

Figure A2: Trends and Prospects of Functionality Development by Increasing Women Directors Share in Finland and Japan.

Journal of Technology Management for Growing Economies, Volume 8, Number 1, April 2017 


$$
\begin{aligned}
& \text { Diffusion trajectory of innovative goods } Y \\
& \text { Simple Logistic Growth (SLG) with fixed carrying capacity }(N) \\
& \frac{d Y(t)}{d t}=a Y(t)\left(1-\frac{Y(t)}{N}\right) \quad \square \quad Y(t)=\frac{N}{1+b e^{-a t}} \\
& \longdiv { 2 } \\
& \frac{d Y(t)}{d t}=a Y(t)\left(1-\frac{Y(t)}{N(t)}\right) \\
& \text { Logistic Growth within a Dynamic Carrying Capacity } \\
& \text { (LGDCC) } \\
& Y=\frac{N_{k}}{1+b e^{-a t}+\frac{b_{k}}{1-a_{k} / a} e^{-a_{k} t}} \\
& N(t)=Y(t)\left(\frac{1}{1-\frac{1}{a} \cdot \frac{\Delta Y(t)}{Y(t)}}\right) \quad \square \quad F D=\frac{N(t)}{Y(t)}=\frac{1}{1-\frac{1}{a} \cdot \frac{\Delta Y(t)}{Y(t)}} \quad \Delta Y(t)=\frac{d Y(t)}{d t} \\
& \text { Self-propagation }
\end{aligned}
$$

Harnessing

Women's

Potential as a

Soft Engine

Figure A3: Dynamism in Incorporating Self-propagation.

\section{REFERENCES}

Catalyst, 2005. Corporate Performance and Women's Representation on Boards. http://www.catalyst.org/media/companies-more-women-board-directors-experience-higher-financial-performance-accoeding-latest/ Retrieved 11 March 2017.

European Commission (EC), 2017. 2017 Report on Equality between Women and Men in the EU, EC, Brussel.

FINNCHAM, 2016. The Sixth Women Directors and Executives Report 2016 - Women Directors on the Rise: Executive Positions Still Going to Men. HINNCHAM, Helsinki.

GMI Ratings, 2013. 2013 Women on Boards Survey. GMI Ratings, New York.

Hofstede, G., 1991. Cultures and Organizations. McGraw-Hill International, London.

International Labour Organization (ILO), 2015. Women in Businesses and Management: Gaining Momentum. ILO, Geneva.

International Telecommunication Union (ITU), 2014. World Telecommunication Indicators Database. ITU, Geneva.

Jia, M. and Zhang, Z., 2013. Critical Mass of Women on BODs, Multiple Identities, and Corporate Philanthropic Disaster Response: Evidence from Privacy Owned Chinese Firms. Journal of Business Ethics, 118 (2), 303-317.

Kim, H., 2015. How is South Korea Closing the Gender Gap? World Economic Forum. http://www. weforum.org/agenda/2015/3qa-how-is-south-korea-closing-the-gender-gap Retrieved 7 April 2017.

McKinsey \& Company, 2007. Women Matter 2007: Gender Diversity, a Corporate Performance Driver. McKinsey \& Company, New York.

McKinsey \& Company, 2016. Women Matter 2016: Reinventing the Workplace to Unlock the Potential of Gender Diversity. McKinsey \& Company, New York.

Ministry of Health, Labor and Welfare of Japan (MHLW), 2013. Health, Labor and Welfare White Paper in Japan. MHLW, Tokyo.

MSCI, 2015. Global Trends in Gender Diversity on Corporate Boards. Women on Boards, November 2015, 1-31. 
Watanabe, $\mathrm{C}$. Naveed, K. Neittaanmäki, P.
Nihon Keizai Shimbun, 2017. Why Firms with Many Women Board Members Perform Better? February $4,2017$.

OECD, 2014. Women, Government and Policy Making in OECD Countries: Fostering Diversity for Inclusive Growth, OECD, Paris.

OECD, 2016. Background Report: Conference on Improving Women's Access to Leadership. OECD, Paris.

UNDP, 2010. Promoting an Economic and Legal Environment for Women's Empowerment, Speech by Helen Clark, http://www.undp.org/content/undp/en/home/presscenter/speeches/2010/03/25/promoting-an-economic-andlegal-environment-for-womens-empowerment-. html UN Women (2015), Collective Failure of Leadership on Progress

United Nations Educational, Scientific and Cultural Organisation (UNESCO), Institute of Statistics, 2014. Women in Science. http://www.uis.unesco.org/_LAYOUTS/UNESCO/women-in-science/index.html\#!lang=en

UNWomen, 2015. Collective Failure of Leadership on Progress for Women. Media Release.

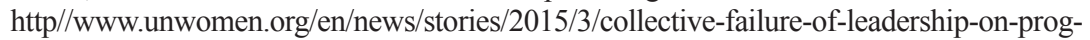
ress-for-women Retrieved 7 April 2017.

Watanabe, C., Kondo, R., Ouchi, N., Wei, H. and Griffy-Brown, C., 2004. Institutional Elasticity as a Significant Driver of IT Functionality Development. Technological Forecasting and Social Change, 71 (7), 723-750.

Watanabe, C., Lei, S. and Ouchi, N., 2009. Fusing Indigenous Technology Development and Market Learning for Greater Functionality Development: An Empirical Analysis of the Growth Trajectory of Canon Printers. Technovation, 29 (2), 265-283.

Watanabe, C., Naveed, K. and Neittaanmäki, P., 2016. Co-evolution of Three Mega-trends Natures Un-captured GDP: Uber's Ride-sharing Revolution. Technology in Society, 46, 164-185.

Watanabe, C., Naveed, K. and Neittaanmäki, P., 2017a. Consolidated Challenge to Social Demand for Resilient Platforms: Lessons from Uber's Global Expansion. Technology in Society, 48, 33 53. https://dx.doi.org/10.1016/j.techsoc.2016.10.006.

Watanabe, C., Naveed, K. and Neittaanmäki, P., 2017b. Co-evolution between Trust in Teachers and Higher Education toward Digitally-rich Learning Environments. Technology in Society, 48, 70-96.

World Economic Forum (WEF), 2016. The Global Gender Gap Report 2016. WEF, Geneva. 